\title{
Why do university spin-offs attract more venture capitalists?
}

\author{
Pedro Ortín-Ángel \\ Universitat Autònoma de Barcelona \\ Edifici B. 080193 Cerdanyola del Valles, Barcelona, Spain \\ Tel. +34 935811451 \\ Fax. +34 935812555 \\ pere.ortin@uab.es \\ Ferran Vendrell-Herrero* \\ Basque Institute of Competitiveness \\ Mundaiz 50. 20012 San Sebastián, Guipúzcoa, Spain \\ Tel. +34 943297327 \\ Fax. +34943279323 \\ fvendrel@orkestra.deusto.es
}

\begin{abstract}
:
This paper provides empirical evidence that young university spin-offs are more likely to receive venture capital than other technological start-ups. In addition, this fact is explained mainly by the lack of managerial skills among the founders of certain university spin-offs. The data used has been obtained from a questionnaire answered by 64 Spanish technological firms founded between the years 1993 and 2005. Forty of the firms are university spin-offs; the remainder are independent technology-based startups. The results support the complementary-assets view that academic entrepreneurs use venture capitalists as a means of gaining access to managerial skills. These results are maintained even when we control for financial constraints, levels of debt and intellectual-property protection. Although these latter variables explain why certain high-tech firms are more likely to receive venture capital, we do not find statistical evidence that they explain the differences between university spin-offs and technological start-ups in terms of being backed by venture capitalists. The results therefore suggest that universities and policy makers can stimulate the creation and growth of university spin-offs by facilitating contact and trust between venture capitalists and academic entrepreneurs, mostly with respect to those cases in which there is a severe lack of managerial skills.
\end{abstract}

Key words: Venture capital, university spin-offs, technological firms, managerial skills. JEL CODES: L20, O32.

* Correspondence author. This work has benefited from comments made by the editors, three blind reviewers and those made at the seminar on the dynamics of science-based entrepreneurship organized in April 2008 (Sestri, Italy). This work has received financial support from the SEJ 2007- 67895-C04-02 and benefited from the database created as part of a joint project involving DGPYME and Fundación ICO prepared in association with Vicente Salas and María Victoria Trujillo. We also appreciate their comments. 


\section{INTRODUCTION}

Research-based university spin-offs have become an important issue within the university technology transfer process (Di Gregorio and Shane, 2003; Wright et al., 2004a and 2004b), attracting more and more interest among academic researchers (Mustar et al., 2006). The main challenge of this literature is to discover and explain the existing differences between university spin-offs and similar technology-based start-ups that have appeared in other environments than those associated with universities.

It is well established in the literature (Colombo and Delmastro, 2002; Shane, 2004) that the founders of university spin-offs usually have more formal education levels - due to their academic origin (Siegel, Waldman and Link, 2003; Ndonzuau, Pirnay and Surlemont, 2002) - but less managerial skills (Shane and Khurana, 2003; Shane, 2004; Vohora et al., 2004) than their counterparts. In fact, Ensley and Hmielski (2005) present evidence from the US that the founders of university spin-offs tend to be more homogenous and have less developed dynamics than those developed by independent start-ups.

Much of the literature has emphasized in other contexts that founding teams are important because their characteristics have an impact on the organizational structure and performance of firms (Kimberly, 1979; Boeker, 1988; Eisendhardt and Schoonhoven, 1990; Baron et al., 1996). There is empirical evidence that this could also be the case with university spin-offs. In this regard, Chrisman et al. (1995) and Ensley and Hmieleski (2005) have reported that university spin-offs on average perform more poorly than independent start-ups but it is not known whether such characteristics have any consequences for their financing policies, and more concretely for their capacity to attract more venture capital.

The existing evidence is restricted to a couple of studies. Toole and Czarnitzki (2007) found that academic entrepreneurs are $2.1 \%$ more likely to obtain venture capital than other entrepreneurs after controlling for different variables. Wright et al. (2006) found that $6.5 \%$ of university spin-off proposals at the seed stage and $13 \%$ of university spinoff proposals at the start-up stage receive venture capital investment while only around $1-2 \%$ of independent start-up proposals at any stage of development are accepted for venture capital investment. In addition, if the rate of proposals is at least the same between university spin-offs and independent start-ups, then the above evidence seems 
to suggest that university spin-offs could have a greater capacity to attract venture capitalists than independent start-ups. Aside from this evidence, there is a lack of research on this topic.

The present paper helps to start filling this gap. In this regard, it provides evidence of the differences in the presence of venture capitalists between university spin-offs and other independent high-tech start-ups in Spain. Of special interest is the provision of insights that might explain such differences, and more concretely test whether the aforementioned differences in managerial skills are one of those possible explanations. The evidence comes from a questionnaire answered in 2006 by 64 Spanish technological firms founded between 1993 and 2005. Forty of the firms were university spin-offs, and for purposes of comparison, the remaining set of firms were independent technology based start-ups.

The paper is organized as follows. The following section develops the hypotheses to be tested from the existing literature by analyzing the determinants of how a high-tech firm is financed by a venture capitalist. The third section presents the research design, the data construction and the methodology for testing such arguments. Section four presents the empirical tests. The paper ends with a discussion of the results and the conclusions.

\section{THEORY AND HYPOTHESES}

The theoretical arguments are borrowed from the literature analyzing the relationships between venture capitalists and high-tech firms. According to initial qualitative studies (Macmillan et al.,1985 and 1987; Muzyka et al., 1996; or Shepherd et al., 2000) based on the perception of venture capitalists, their basic requirement is for managers to have managerial experience and industry-related competence. Recent quantitative evidence is consistent with this view (Patzelt et al., 2009; Dawson, 2009). By extension, it could be argued that the lack of managerial skills of academic entrepreneurs could imply more difficulties in attracting venture capital. This would be the case if all high-tech firms demand venture capital funds.

A usual theoretical framework for understanding the presence of venture capitalists in high-tech firms, the pecking order argument (Roberts, 1991; Watson and Wilson, 2002) suggests that this will not be the case. When technological entrepreneurs decide on their firms' financial structure, a major concern is to pursue the protection of their 
innovations and consequently their economic income, at least during the early stages of the project. Consequently, in order to avoid equity dilution they will first prefer to provide themselves with the required funds. Giudici and Paleari (2000) and Brau and Fawcett (2006) present evidence that an important goal of those entrepreneurs is to preserve decision-making control and ownership. This opens the question of which firms are going to be more interested in being backed by venture capitalists.

Departing from the complementary assets view first presented by Teece (1986):

"In almost all the cases, the successful commercialization of an innovation requires that the know-how in question be utilized in conjunction with other capabilities or assets. Services such as marketing, competitive manufacturing and after sales support are almost always needed" (p.288).

Colombo and Grilli (2009) suggest that venture capitalists not only supply finance but also complement the firms' assets as they finance them. Venture capitalists could provide direct consultancy services contributing to managerial "professionalization" or, even if they do not provide this directly, they could nevertheless facilitate access to such services. There is some previous evidence that supports this argumentation. Kaplan and Stömberg (2004) observe that venture capitalists that have more participation in the firm tend to be more integrated in its management. Baum and Silverman (2004) present evidence that venture capitalists finance start-ups that have strong technology but are at risk of failure in the short run, and therefore have the need of managerial expertise. Finally, Hellman and Puri (2002) and Beckman et al. (2007) show that venture capitalists alter the founding team with positive consequences on the performance of the firm.

So we have two contradictory predictions. From the complementary assets view (Teece, 1986; Colombo and Grilli, 2009) it seems that university spin-offs are more likely to seek venture capital than other independent technological start-ups. From the criteria selection of venture capitalists (Macmillan et al., 1985 and 1987; Muzyka et al., 1996; or Shepherd et al., 2000) it seems that independent technological start-ups will be more likely to be backed.

The existing evidence on the likelihood of acquiring venture capital funds by high-tech start-ups could shed some light on this debate. Clarysse et al. (2007a) found that teams composed of founders with a lack of managerial skills are more likely to receive venture capitalists' funds and develop boards with external members that have skills which 
complement the founding team. Moreover, Shane and Stuart (2002) found a negative and significant relation between founding teams with previous start-up experience and the reception of venture capital. Finally, this evidence was complemented by Heirman and Clarysse (2004). From a dataset of 99 Belgium firms they showed that start-ups that receive venture capital have a lower amount of managerial and sector experience than those defined as transitional or product start-ups. The results above seem to suggest that the complementary assets view could prevail. As one would expect university spin-offs to have a lack of managerial skills in comparison to high-tech independent start-ups, the above arguments can be summarized by the following hypothesis:

Hypothesis 1: The likelihood of being backed by a venture capitalist is higher in university spin-offs than in independent start-ups.

A test of the above hypothesis requires two samples of firms, one of university spin-offs and another of independent start-ups. In fact, the above hypothesis assumes that there is variability in the presence of venture capitalists between groups or samples, but does not ask for the causes of such variability. So Hypothesis 1, in itself, does not provide evidence that such differences are really explained by the complementary assets view, or more concretely, by differences in managerial skills. If the differences in managerial skills explain part of such variability between groups, one would also expect the differences between university spin-offs and independent start-ups to diminish or even disappear when the managerial teams of one and another firm have similar managerial skills.

Hypothesis 2: The likelihood of being backed by a venture capitalist is the same for those university spin-offs and independent start-ups founded by teams with the same managerial skills.

Obviously, differences between the management teams are not the only explanation provided in the literature for why a high-tech firm could acquire venture capital, so it is important to control for such alternative explanations. Consistently with the pecking order argument, Chandler and Hanks (1998) postulate that the amount of funds initially provided by the entrepreneurs may result from contributing all they can give to the business. Therefore demand for venture capital finance may come disproportionately from high-tech firms with higher required investment (such as R\&D expenditure), or in 
other words from those firms in which the limited resources of the entrepreneurs entail financial constraints (Westhead and Storey, 1997).

The existence of financial constraints is difficult to detect. At least two variables seem relevant, the wealth of the entrepreneurs and the project funding requirements. The entrepreneurs' wealth, even proxy variables such as human capital and the age of the founders (Xu, 1998; Astebro and Bernhardt, 1999), are usually unavailable to researchers. Assuming that the wealth of the entrepreneurs is independent of the firms financed, one would expect that the higher the assets per entrepreneur of a firm, the lower the capability of providing funds will be. So one alternative explanation for why university spin-offs have more venture capital could be that they have more financial constraints.

The existing evidence about the relationship between the number of founders and the presence of venture capital is based on univariate analysis (correlations and differences of means), and the results are contradictory. While some studies do not find a significant relationship (Stuart and Abetti, 1990; Almus and Nerlinger, 1999; and Clarysse et al., 2007a), some find a positive one (Cooper and Bruno, 1977; Roberts, 1991; Heirman and Clarysse, 2004) and other authors (Van de Ven et al., 1984) a negative one. Recent works performing multivariate analysis that have taken into account the number of founders and the size of the firm also have contradictory results. While Beckman et al. (2007) found that both variables have a positive and significant influence in enhancing venture capital reception, Hogan and Hutson (2005) found that while the size of the initial founding team has a negative (but non-significant) effect, the size of the firm significantly raises the probability of receiving venture capital. Notice that the latter is consistent with financial constraint arguments.

Furthermore, the pecking order argument also implies that when a contributor's funds are exhausted, debt is preferred to venture capital. Obviously, when contributors do not have such funds, debt seems to provide more protection of their innovations than venture capital. The founders can more easily limit access to relevant technological information to creditors than to such other shareholders as venture capitalists. So venture capitalists are only going to be used when firms have no further access to debt. Consequently, a positive correlation is expected between the presence of venture capital and a firm's level of debt. Previous evidence from a sample of 8,100 small and medium 
firms in the US found a positive and significant relation between the use of bank loans and the likelihood of the presence of venture capital (Ou and Haynes, 2006). Those authors suggest an alternative interpretation of these results based on the idea that different entrepreneurs' attitudes to risk will influence the financial structure of firms. Summing up, another alternative explanation for why university spin-offs have more venture capital could be that they have higher levels of debt.

Following the pecking order argumentations, when the founder's inventions are not well-protected, the venture capitalist can transmit this informal knowledge to other firms with which they are cooperating or investing. So in the cases in which founders are able to protect their innovations, or intellectual property, this risk is lower, so a higher presence of venture capitalists is to be expected. This relationship has also been justified by other arguments. Hellman and Puri (2000) suggest that in an environment with imperfect information on the quality of the projects, intellectual property protection is a way of signaling good projects and therefore attracts the attention of venture capitalists (Mann and Sager, 2007).

Previous evidence supports this prediction. It has been shown that intellectual property protection (through patents) influences the investment decisions of venture capitalists (Baum and Silverman, 2004) namely because patents signal quality and because patented technology is potentially more easy to sell. Hellmann and Puri (2000) find that those firms that follow an innovative strategy are more likely to obtain venture funding than imitating firms. Shane and Stuart (2002) found that each patent registered by a firm increases the probability of having venture capital funds by $2.7 \%$, although their results are not statistically significant. Colombo et al. (2006) estimate an increase of $5.2 \%$ in the likelihood of having a commercial alliance and 3.5\% of having a technological alliance for each patent registered. Engel and Keilbach (2007) found evidence that having registered patents increases the probability of the venture capitalist getting involved in the financing at start-up. Clarysse et al. (2007b) found that university spinoffs with formal technology transfer (patents) raise a large amount of capital at start-up. Some authors (Arora et al., 2001; Bessen and Meurer, 2008) show that the viability and effectiveness of intellectual property protection through patents is highly sector specific and is also strongly related with the nature of the technology. An alternative explanation for why university spin-offs have more venture capitalists than independent start-ups 
could be the nature of the technology developed that makes it potentially more patentable.

Note that the described factors do not exhaust the possible explanations for why university spin-offs can be more backed up by venture capitalists than independent start-ups. Macho et al. (2007) argue that Technological Transfer Office (TTO) has a reputation to maintain, so university spin-offs will have on average better entrepreneurial projects attracting more venture capital. Wright et al. (2006) made an exploratory study in order to find out about TTO directors' perceptions of venture capital. From 11 interviews with UK TTOs they found that those institutions had a clear preference for external finance or venture capital. So although the mentioned factors such as managerial skills, financial constraints, degree of debt or intellectual property protection can explain part of the variability between university spin-offs and independent start-ups, part of such variability could remain unexplained by the idiosyncrasies of universities, such as, for example, the presence of TTO's.

Summing up, the existing literature has analyzed the factors explaining the variability in the presence of venture capitalists within high-tech start-ups (see Champenois et al. (2006) for a summary), but remains silent about the variability between university spinoffs and independent start-ups. So, our purpose is to shed some light on this issue.

\section{RESEARCH DESIGN}

\section{Data Construction}

In order to test the hypotheses formulated we constructed two comparable databases of young independent technological start-ups and university spin-offs in Spain. Obviously the main problem is that in Spain there is neither official nor unofficial census of these kinds of firms. So for the case of university spin-offs the first step was to identify some of them. Between March and April 2006 we contacted the Technological Transfer Office (TTO) of the 58 Spanish public universities existing at that time. 37 of those offices attended to our requirements, an answer rate of $64 \%$. Nine of these TTOs reported that they did not have spin-offs yet but they were interested in their creation. The other TTOs sent us a list with contact information for the spin-offs, which was complemented with information available on different web pages. Thus, we were able to electronically contact 495 Spin-offs from 28 Spanish universities. 
In fact, there are different definitions of the phenomenon of university spin-offs. The range goes from restrictive (Shane, 2004) to wide definitions (Roberts, 1991). In this regard, Shane (2004) defines the university spin-off as a new company founded to exploit a piece of intellectual property created in an academic institution. On the contrary, Roberts (1991) defines university spin-offs as firms founded by anyone that worked or studied at a university. In order to be sure about the definition used by the TTOs to classify a firm as a spin-off, we asked them. The vast majority coincide with Roberts' definition of considering spin-offs to be those companies where the founders have previously been members of a university (students or professors) and the TTO has taken a relevant role in the creation of that company.

The second step was to send a questionnaire to those spin-offs. Between June and September of 2006 the questionnaire was sent to the founders of the university spin-offs using Survey-Monkey services ${ }^{1}$. The questionnaire was previously tested with experts on these topics ${ }^{2}$.

The number of finally answered questionnaires was 72. After removing incomplete answers the sample was reduced to 40 firms, $8 \%$ of the initially identified university spin-offs. From Column 1 in Table 1 we observe that the average age of the firms is 5 years and all of them were founded between 1993 and 2005. The firms have been selfclassified into five different sectors, Computer Science, Chemical, Pharmaceutics, Biotechnology and Research \& Development ${ }^{3}$. All these industries are typically considered high-tech as their proportion of employees and expenses dedicated to R\&D activities is normally relatively large (Stohr, 1986). Moreover, according to Schartinger et al. (2002) while Computer Science, Chemical, Biotechnology and Pharmaceutics industries are directly related to a field of science, the other set of high-tech firms is more diversified or covers other scientific fields. Those firms are classified under the NACE'2008 as Research and Development. In more detail, our set of firms in this category offers consultancy services in $R \& D$ in a technological domain to other firms covering their outsourcing requirements. As shown in Appendix 1, firms were free to specify other sectors than those enumerated earlier, but for the answers provided no

\footnotetext{
${ }^{1}$ See www.surveymonkey.com for more information.

${ }^{2}$ The experts belong to the Spanish institute of small and medium firms (DGPYME). Among them, Maria Callejón, the general director of policies concerning Small and Medium firms at the Spanish Ministry of Industry and also a full professor at the University of Barcelona and a specialist in these topics.

${ }^{3}$ With the exception of Biotechnology, the remainder correspond to the following NACE'2008 codes (62, 20, 21, and 72 respectively http://ec.europa.eu/comm/competition/mergers/cases/index/nace_all.html).
} 
other relevant sector was identified. The most representative sector is Computer Science (37.5\%). It is followed by Research and Development $(R \& D)$ with $25 \%$ of the firms, Chemical with $22.5 \%$, Biotechnology with $15 \%$ and Pharmaceutics with $5 \%$.

\section{[Insert Table 1 about here]}

In order to compare university spin-offs with other technological start-ups we constructed a comparative sample looking for firms created in 1993 or afterwards belonging to one of the five economic sectors described earlier. In order to identify those firms and their contact information we followed Quintana-García and BenavidesVelasco's (2005) strategy of looking for those firms on the website of the Centro para el Desarrollo Tecnológico Industrial ${ }^{4}$ (CDTI). This strengthened the criteria for selecting a firm as being technological, as the economic sector and a public institution has identified them as being so. A possible drawback is that this procedure could introduce some biases. The identification is based on the aids provided by the CDTI. The main criteria used for providing such aids are the entrepreneurial viability of the innovation project, so this seems to be the most important potential bias. Colombo et al. (2007) suggest that the presence of venture capitalists could be used by public institutions as a positive signal for providing aids. So, a priori, if some bias is expected, our comparative sample would have a greater presence of venture capital than the population of high-tech start-ups. We were at least able to list 167 firms.

In the case of the comparative sample, the e-mail addresses were not available, so the questionnaire was sent by post ${ }^{5}$ between October 2006 and January 2007, obtaining 29 answers. Before sending the questionnaires we checked that none of the firms were on the list of university spin-offs and after receiving the questionnaire we checked that none of the founders of the CDTI firms were contractually linked with universities and that all of them were working in other companies before founding the start-up. After removing incomplete answers our sample was reduced to 24 firms, an answer ratio of $15 \%$. As the questionnaire sent to university spin-offs and technological start-ups was the same, we did not expect differences between samples in terms of the firms that did not answer it. Table 1 compares the characteristics of both samples.

\footnotetext{
4 This is a public organization depending on the Spanish Ministry of Industry, Tourism and Commerce, that promotes the innovation and technological development of Spanish companies. It grants technological companies their own financial aid and facilitates access to other sources of finance. For more information see www.cdti.es

${ }^{5}$ We contracted the services of TNS-Demoscopia, a Spanish firm specialized in surveys.
} 
Table 1 shows that on average the firms in the full sample have an age of 5.7 years and were founded with 2.7 employees. Independent start-ups are older and initially have more employees, but only the differences for age in relation to university spin-offs were statistically significant at the $10 \%$ level. The most representative sector in the full sample is Computer Science (31\%). It is followed by Research and Development $(R \& D)$ with $28 \%$ of the firms, Chemical with $19 \%$, Biotechnology with $16 \%$ and Pharmaceutics with $6 \%$. In the independent start-ups sample, the representation of Computer Science is lower than in the university spin-offs sample, with a higher representation of the Research and Development sector. However, we can not reject (at the usual levels of significance) that the distribution of sectors is the same for both samples.

\section{Definition of variables}

A cross-section analysis will be conducted with the information extracted from a broad questionnaire addressed at the current managers of the firm and structured into two blocks, the first part focused on the current characteristics of the firm and the second on those at the moment of foundation (see Appendix 1). The fact that in most cases (86\%) the initial entrepreneurs are still in the firm, coupled with the short life of the firms (on average less than 6 years), made us confident about the answers relating to foundation, or more concretely founding team size and the managerial skills of the founders prior to foundation.

The research question is related with the presence of venture capital in the firms. Therefore the dependent variable is a dummy $(V C)$ that measures whether the firm is currently financed by venture capitalists (value 1) or not (value 0). As shown in Table 2 only $14 \%$ of the firms in the sample have received such funds. This ratio is close to that identified in similar studies. For example, Heirman and Clarysse (2004) and Clarysse et al. (2007a) use Belgian samples in which $12-13 \%$ of the companies received venture capital.

The hypotheses have been formulated in terms of differences between university spinoffs and high-tech independent start-ups. For that purpose the dummy variable University Spin-off (USO) is used. This variable takes the value one for university spinoffs and zero otherwise. As shown in Table 2 university spin-offs finally represent 
$62.5 \%$ of the sample and $89 \%$ of the firms financed by venture capitalists, which seems consistent with Hypothesis 1.

\section{[Insert Table 2 about here]}

Based on the complementary assets arguments, Hypothesis 2 postulates that the greater presence of venture capital is due to differences in managerial skills. Stuart and Abetti (1990) suggest that the required knowledge for managing a firm comes almost exclusively from practical experience and/or creating a new firm. Each of the founding members of the firms was asked whether they had any background in practical management at the time of foundation or whether they had created a company before. This also enabled us to avoid problems with reverse causality, due to all the venture capitalists joining the firm after its foundation. In all the independent start-ups at least one founder claims to have practical managerial experience, while in $35 \%$ of the university spin-offs none of the founding members recognized any kind of previous managerial experience. Notice that this distribution is consistent with previous literature (Shane and Kurhana, 2003; Ensley and Hmieleski, 2005). So to test Hypothesis 2, the university spin-offs were classified into two groups, (i) USO with lack of managerial skills compared to independent start-ups (none of the members of the founding team had managerial experience) and (ii) USO with equal managerial skills as independent startups (some or all of the members of the founding team had managerial experience).

The theoretical section emphasizes the need to control for alternative explanations. More concretely, previous studies suggest that the presence of venture capitalists in high-technology firms can be related with the financial constraints of the firm, its degree of debt or its intellectual property protection.

As discussed in the theoretical section, the measurement of financial constraints is difficult. At least, the total financial requirements can be measured by the total assets of the firm. This information is only available for some firms but there are many missing values. One variable that is highly correlated with the total assets of the firm (Hopkins, 1988 ) is the number of employees (in our case it can explain $66.56 \%$ of the total asset variability). As this variable usually has a skew distribution, previous empirical studies transform it into logarithms. As in our case this enhances the explanatory power of the models, we will also use their logarithm (Ln current employees). According to Table 2 the projects that receive venture capital tend to be less ambitious (7.88) than the 
remainder (13.29). This could be because we can not control for the number of entrepreneurs that can provide such funds. The only variable available to approximate this is the number of founding members. For each firm we have a list of founding members. This information enabled us to compute the founding team size. For a similar sample of university spin-offs Vendrell-Herrero (2008) found that over the 2000-2005 period (information prior to 2000 was unavailable) there were only changes in the board of directors in $11.5 \%$ of the spin-offs (half of them featured appointments and resignations while the remainder only featured appointments). Given the low number of changes, the initial number of founders seems fairly correlated with the present number of board members. Note that the present number of board members can include not only entrepreneurs, as desired, but also venture capitalists, which to be consistent with the theoretical arguments would have to be excluded. In the sample the average number of founding members is 2.77. As predicted, firms that have not received venture capital funds on average have larger teams, 2.91 members, than firms with such funds, 1.89 members.

The degree of debt can also affect the presence of venture capital. Like Colombo and Grilli (2007) the degree of debt is computed by the proportion of the current leverage ratio as total debt (or liabilities minus equity) over total liabilities ${ }^{6}$. As can be seen in Table 2, debt represents $47.9 \%$, on average, of the total liabilities of the firms in the sample. Consistent with the theoretical framework presented, venture capitalists have higher debt ratios (53\%) than other firms (48\%). It is important to note that in 15 firms equity represents $100 \%$ of the total liabilities ${ }^{7}$.

Intellectual property protection can also favour the presence of venture capital. Although patents have been used as a proxy for intellectual property protection, Arora et al. (2008) argue that firms patent an invention when the property right provides additional income in comparison with alternative means of appropriating value, what they call "patent premium", consequently the amount of patents is not sufficient to approximate intellectual property protection. In order to complement the information on patents, and following Shane and Stuart (2002) and Colombo et al. (2006), IP

\footnotetext{
${ }^{6}$ Note that by definition the total liabilities are equal to total assets, what makes it difficult to introduce both variables to the same estimations. In our case this is solved by using the current employees variable.

${ }^{7}$ All the analyses have been replicated including a dummy variable for these cases, and the results are basically the same. The tests are available from the authors upon request.
} 
protection is measured as the sum of the current stock of licenses ${ }^{8}$, patents, and the firm's own brands ${ }^{9}$. The mean is 1.32 rights over innovations per firm, see Table 2, but while 15 is the highest number of rights for one firm, 27 firms (42.2\% of the sample) have no intellectual property protection. Given that 13 firms (20\% of the sample) did not answer the variable referring to IP protection, and in order to have as many observations as possible, we considered the number of rights of such firms as zero and created a dummy variable, Unknown IP protection, with a value of one when the firm did not answer the questions about its IP protection rights and zero otherwise. The results omitting this last variable are practically the same but their statistical significance is lower given the reduction in the number of observations. Consistent with the theoretical framework presented, the average amount of IP protection is greater among those firms that have received venture capital (1.55 vs. 1.29, see Table 2 ).

This is a cross-section study, but two variables were measured at the time of foundation (size of the team and managerial skills). Given that the level of changes produced in those variables since the foundation until now can be correlated with the age, and the differences in the ages of firms' between the two samples analyzed are statistically significant (at $10 \%$ level, see Table 1), we controlled in the estimations for the variable Age of the firm. It is worth noting that firms are, on average, of a similar age whether they received venture capital funds (6) or did not (5.58), see Table 2.

We also controlled for the economic sector in the regressions. By some difference, Computer Science is the sector that accumulates the largest number of firms, is the one whose representation changes most between university spin-offs and the comparative sample, and is the only one that in other tests presented some specificity with respect to the other economic sectors ${ }^{10}$. Therefore it is the only economic sector considered. The dummy variable Computer Science takes the value one if the firm belongs to this economic sector and zero otherwise. The proportion of firms belonging to Computer Science is larger when the firms do not receive venture capital funds $(32.7 \%)$ in comparison to when they do (22.2\%), see Table 2.

\footnotetext{
${ }^{8}$ We test whether the age of the firm depends on the current stock of formal innovations. The parameter was positive but far from significant. Consequently we cannot reject the null hypothesis that the parameter equals zero.

${ }^{9}$ Note that this variable can be interpreted simply as the innovative output. The limitation would then be that it does not take into account other types of innovation (i.e. informal innovation).

${ }^{10}$ These tests are available from the authors upon request.
} 


\section{EMPIRICAL TESTS}

Our first concern was to test whether university spin-offs are more likely to be financed by venture capitalists (Hypothesis 1). To test this, we estimated (via PROBIT and LOGIT models) Model 1 where the dependent variable is venture capital (VC) and the independent ones are university spin-offs (USO) and the set of control variables: the economic sector and the age of the firm. Table 3 presents the results.

\section{[Insert Table 3 about here]}

The only significant coefficient is university spin-offs, which is positive and statistically significant at the 5\% level. In particular, ceteris paribus, from the LOGIT estimation university spin-offs are $18.5 \%$ more likely to have relations with a venture capitalist than independent start-ups. This result supports Hypothesis 1.

Our second concern is to find possible explanations for such differences. Table 4 presents the tests. Model 4 shows estimations of the log-likelihood of being backed by a venture capitalist using as independent variables differences in managerial skills and all the control variables defined in the section above, current employees, team size, degree of debt, IP protection and unknown IP protection, age and Computer Science. Although the comments will be based mostly on such estimations, references will be made to the other models presented in Table 4 omitting some of the independent variables mentioned above.

\section{[Insert Table 4 about here]}

The complementary assets perspective, summarized in Hypothesis 2, suggests the differences in managerial skills as one possible explanation for the differences detected when testing Hypothesis 1. For this purpose, we substitute the independent variable used in Model 1, university spin-offs (USO) with the variables USO with a lack of managerial skills (a dummy variable with value one when the university spin-off has a lack of managerial skills) and the variable USO with equal managerial skills (takes value one when the university spin-off has the same managerial skills as independent start ups). As predicted by Hypothesis 2, the variable USO with equal managerial skills is not statistically significant at the usual levels. Hence, when the managerial skills are the same, university spin-offs and independent start-ups have the same probability of being backed by a venture capitalist. Consequently, only those university spin-offs with 
a lack of managerial skills with respect to independent start-ups have a statistically significant $(1 \%$ level) greater likelihood of having venture capital. This happens independently of the control variables finally used in the estimation (Model 4 and Model 2) ${ }^{11}$. From the LOGIT estimation in Model 4, ceteris paribus, university spin-offs without managerial skills in their founding team are $11.82 \%$ and $11.66 \%$ more likely to receive venture capital than independent start-ups and university spin-offs with managerial skills respectively (this last difference, $11.66 \%$, is statistically significant at the $5 \%$ level).

Furthermore, the difference in managerial skills is the only explanation for differences between university spin-offs and high-tech independent start-ups that receive support. When only the control variables are considered, Model 3, the coefficient of the variable USO is statistically significant (5\% level) and even greater (although the differences are not statistically different ${ }^{12}$ ) than that estimated in Model 1 , Table 3 . So in this case the variables current employees, team size, degree of debt, IP protection, and unknown IP protection do not have statistical significant power for explaining the differences in the likelihood of being backed by venture capitalists between university spin-offs and independent start-ups. Although the set of the control variables used do not explain the differences between the two kinds of firms analyzed, it can (in fact does) explain part of the variation in the likelihood of being backed by venture capitalists within technology based start-ups.

The firm size (Ln current employees) has a non-significant effect while team size has a negative and statistically significant (5\% level) effect on the probability of receiving venture capital. Ceteris paribus, single teams have $27.42 \%$ higher probability of acquiring venture capital funds than two-member teams. Altogether, we have partial evidence for the financial constraint argument. While smaller founding teams enhance the likelihood of venture capital reception, the size of the project measured by current employees has non-significant effects.

\footnotetext{
${ }^{11}$ Furthermore, the idea can not be rejected, at the usual levels of significance, that the differences between the coefficients associated with managerial skills estimated in both models 2 and 4 are zero. Prob $[($ USO with lack managerial skills in Model 2$)=($ USO with lack of managerial skills in Model 4$)]=$ 0.1669 and 0.1864 in the PROBIT and LOGIT estimates respectively. Prob [(USO with equal managerial skills in Model $2=U S O$ with equal managerial skills in Model 4)] $=0.4569$ and 0.5541 in the PROBIT and LOGIT estimates respectively.

${ }^{12}$ Prob $[($ USO in Model 1$)=($ USO in Model 3$)]=0.4164$ and 0.5653 in the PROBIT and LOGIT estimates respectively.
} 
The degree of debt has a positive but non-significant relation to venture capital, which entails little evidence about the argument that higher levels of debt imply higher probabilities of receiving venture capital. Regarding the degree of IP protection we observe that in those firms with a higher number of patents, licenses and their own brands there is a greater and statistically significant (5\% level) presence of venture capitalists. In fact, ceteris paribus, the introduction of 10 patents, licenses or own brands (from a firm without previous protected innovations) implies an increment of $6.37 \%$ in the probability of receiving venture capital funds. Consequently, as the amount of $I P$ protection implies better legal protection capacity of innovations, the above result supports the prediction that well-protected technology facilitates agreements with external parties. Neither the sector nor the age of the firm is statistically significant.

\section{DISCUSSION AND CONCLUSIONS}

The lack of managerial skills has been largely emphasized as one of the main differences between university spin-offs and high-tech independent start-ups (Colombo and Delmastro, 2002; Shane and Khurana, 2003; Shane, 2004; Vohora et al., 2004). This paper provides a preliminary analysis of the consequences of such differences on the presence of venture capitalists. From a questionnaire answered by a sample of 64 firms, which included 40 Spanish university spin-offs and a comparison sample of 24 high-tech independent start-ups, we found that on average, university spin-offs are more likely to have venture capital than independent start-ups (Hypothesis 1). In our sample this is basically explained by the greater presence of venture capitalists in those university spin-offs whose founding team has a lack of managerial skills (Hypothesis 2). Despite the limited size of the sample, these results are statistically significant.

Those results can be related with the existing literature on the determinants for venture capital to back a high-tech firm. Initial qualitative studies analyzing the venture capitalists' preferences (Macmillan et al., 1985, 1987; Muzyka et al., 1996; Shepherd et al., 2000) find that they prefer to finance those founders with higher skills. On the other hand, papers analyzing the entrepreneurs' preferences (Brau and Fawcett, 2006; Giudici and Paleari, 2000) confirm the suggestions of the pecking order argument, entrepreneurs prefer to preserve decision-making control and ownership, so they will look for venture capital only when it is needed. From the complementary assets theory (Teece, 1986) some authors suggest that the new technology based firms need venture capital in the 
case of a lack of managerial skills. In fact, with data at firm-level, empirical studies find evidence that founders with less managerial skills have a greater likelihood of receiving venture capital funds (Shane and Stuart, 2002; Heirman and Clarysse, 2004; Baum and Silverman, 2004; Clarysse et al., 2007a; Beckman et al., 2007; Colombo and Grilli, 2009).

A limitation of the data, also shared in our case, is that information only appears about the agreements that were actually made between venture capitalists and founders. So we do not directly observe which entrepreneurs have asked for venture capital, or whether they have received offers from venture capitalists. Previous empirical evidence (Wright et al., 2006) suggests that venture capital firms put their effort into searching for major projects and await proposals from those entrepreneurs that need their external funds. In the case of Spain, Martí-Pellon (2002) classifies major projects to be those requiring a first investment equal to or higher than $€ 3$ million. In the sample analyzed, no firm required this investment at the stages taken into account. In that regard, the evidence is interpreted as a way of understanding the reasons that lead entrepreneurs to seek venture capitalists, in particular academic ones. Obviously, further research is needed to confirm that the results really are due to differences in the behaviour of entrepreneurs.

The evidence presented here supports the hypothesis developed from the complementary assets theory (Teece, 1986) that university entrepreneurs with less managerial skills will require more venture capital funds. Those university spin-offs created by founding teams without managerial skills are less competitive than other start-ups (Ensley and Hmieleski, 2005). One way of reducing such limitations is to find people that can provide such complementary abilities (Teece, 1986). Venture capitalists could be one source. As we do not provide direct evidence that they are really providing it, the evidence is also consistent with the idea that venture capitalists are not providing such assets but guiding entrepreneurs and positioning the firms closer to the correct networks for acquiring it. In one or another case, venture capitalists are facilitating the access, directly or indirectly, to such complementary abilities.

In fact, our data only supports the complementary assets theory (Teece, 1986) as an explanation for the finding that venture capital is more present in university spin-offs than in independent start-ups (Wright et al., 2006; Toole and Czarnitzki, 2007). Given the low number of observations available we have to be cautious when rejecting other 
possible explanations such as financial constraints, the level of debt, intellectual property protection or the role of TTO. Perhaps, a more prudent interpretation of our results is that, at least, the lack of managerial skills is the most significant explanation for the greater presence of venture capitalists among university spin-offs than in independent start-ups.

However, the pecking order argument seems to be a coherent argument in explaining the variability in the presence of venture capitalists within high-tech start-ups. This argument postulates that venture capital will be the last financial resort when firms have low protection of the economic income coming from their inventions. From those arguments we derive predictions on the influence of financial constraints, level of debt and intellectual property protection in the likelihood of being backed by venture capital. Our results partially support those predictions. While the correlation between the degree of debt or the current employees with venture capital reception are statistically nonsignificant, but with the predicted sign (positive) in most cases, the other two analyzed variables are significantly in line with the pecking order argument. The amount of founders (which proxy their wealth) significantly diminishes the likelihood of having venture capital funds, which supports the financial constraint prediction, and the degree of intellectual property protection (IP protection) significantly supports the prediction that protected technology facilitates agreements.

Although the pecking order argument seems a consistent explanation for all the above results, other interpretations, ad hoc for the different control variables, have been included in the literature. Hellman and Puri (2000) and Mann and Sager (2007) emphasize the signalling role of the intellectual property protection that facilitates the access of firms to venture capital funds. Regarding debt, Ou and Haynes (2006) point out that entrepreneurs' attitudes to risk will influence the financial structure of firms, predicting some complementarities between debt and venture capital. From the empirical evidence provided we can not rule out any of those or other possible interpretations.

Moreover, as the presence of venture capital and all of the control variables are contemporaneous, with the exception of the size of the founding team, the reverse causal explanation for the effects of such control variables can not be ruled out. For example, Kortum and Lerner (2000) indicate that the presence of venture capitalists' 
investments positively affects innovative output. Intellectual property protection has been interpreted as a measure of firms' innovative output (Shane and Stuart, 2002; Colombo et al., 2006) although it has often been criticized: "patents are primarily legal titles that protect the output of an innovation process from being copied" (Engel and Keillbach, 2007, p. 155), given that they are not measuring any other kind of innovation.

Obviously, reverse causality is inherent to cross-section studies. Furthermore, in crosssection studies we can only observe whether the firm now maintains, or not, a venture capital relationship. When the reasons why a venture capital relationship is established or broken are the same, then the moment of entry and exit are irrelevant and the results from cross-section studies are valid for understanding both phenomena. Academia has focused very little on such venture capital exits as trade or liquidations (Giot and Schwienbacher, 2007), which are the relevant for our sample of firms, given that no university spin-off has been listed in the stock market. So we do not know whether reasons for exit might be quite different from those for entry, and hence the possible implications for the interpretation of our results. Only future studies with panel data can solve these problems of reverse causality and test for differences in the factors that influence how venture capitalists enter or exit a new technology based firm.

Although a priori we do not expect relevant biases in the sample, we have to be cautious when extending our findings to other situations, and consequently deriving policy and managerial implications. Given their limited operating history, independent start-ups or university spin-offs have been identified by Cassar (2004) as the most opaque firms in the economy with respect to information. An example of that is the unavailability of a census either for high-tech firms or for university spin-offs, at least in Spain. The consequence is that we can not compare our sample with the population in order to understand their representativeness. Although no major biases are expected, as commented in the sample description, only more efforts to identify such populations can confirm our expectations.

The evidence has been generated in a specific context, Spain. The structure of ownership and property rights to university inventions is fairly similar to that of the US and other countries (Geuna et al., 2003). Perhaps the main difference with respect to the US is the more predominant role of state universities, but this is common in other 
countries like France, Italy and the UK. In this sense, previous empirical work (Ortín et al., 2008) with the same data provides evidence that the main characteristics of Spanish university spin-offs are fairly similar to other countries (Roberts, 1991; Chrisman et al., 1995; Shane 2004 or Vohora et al., 2004, Ensley and Hmieleski, 2005) especially in terms of the founders' lack of managerial skills. On the other hand, the venture capital market in Spain is less developed than in other countries in terms of the total volume of resources and projects (Martí-Pellon, 2002). Although this is true, the presence of venture capital in the firms analyzed is fairly similar to that obtained in other countries like Belgium (Heirman and Clarysse, 2004 or Clarysse et al. 2007a). So, a priori, the analyzed context does not seem particularly different to other European countries, but more evidence is needed from other institutional contexts to confirm such expectations.

While such evidence is generated, the theories supported have managerial and policy implications. University entrepreneurs must be especially aware of their managerial capabilities and experience. If the founding team has sufficient managerial skills, venture capital seems to be a last resort for obtaining resources, particularly if their innovations are not (or cannot be) well protected. But, in the cases where their managerial experience is low, venture capitalists can be a complement in gaining access to such abilities. Their concern has to be whether this is the most efficient way of obtaining it. The association with venture capitalists can increase the risk of losing the economic income from some innovations.

The results could also be of interest to policy makers, mostly those in charge of public programs that stimulate venture capital ${ }^{13}$ and/or the commercialization of academic innovation ${ }^{14}$. The results show that university spin-offs with founders that have a lack of managerial skills could be more interested in incorporating venture capital than other high-tech firms. Policies facilitating contact, information transmission and trust between venture capitalists and TTOs could enhance and stimulate the extension of venture capital and, as is also pursued, in those sectors with more added value.

\footnotetext{
${ }^{13}$ See Lerner $(1998,2002)$ for a review of such programs.

${ }^{14}$ For example the US SBIR program (Toole and Czarnitzki; 2007) or the Spanish Innova Program (Del Palacio et al., 2006).
} 


\section{REFERENCES}

Almus, M. and Nerlinger, E.A. 1999. Growth of new-technology-based firms: which factors matter. Small Business Economics 13(2), pp. 141-154.

Arora, A. Fosfuri, A. Gambardella, A. 2001. Markets for Technology: The economics of innovation and corporate strategy. The MIT press, Cambridge MA.

Arora, A., Ceccagnoli, M., Cohen, W. 2008. R\&D and the patent premium. International journal of Industrial Organization,26(5), pp.1153-1179..

Astebro, T., Bernhardt, I. 1999. The winner's curse of human capital. Working paper CES 99-5, Centre for economic studies, U.S. Department of Commerce.

Baron, J.N., Burton, M.D., Hannan, M.T. 1996. The Road taken: Origins of employment systems in emerging companies. Industrial and Corporate Change 5, pp.239-275.

Baum, J.A.C, Silverman, B. 2004. Picking winners or building them? Alliance, intellectual, and human capital as selection criteria in venture financing and performance of biotechnology start-ups. Journal of Business Venturing 19, pp. 411-436.

Beckman, C.M., Burton, M.D., O’Reilly, C. 2007. Early teams: The impact of team demography on VC and going public. Journal of Business Venturing 22, pp. 147-173.

Bessen, J., Meurer, M.J. 2008. Do patents perform like property ? The Academy of Management perspectives 22 (3), pp. 8-20.

Boeker, W. 1988. Organizational origins: entrepreneurial and environmental imprinting at time of founding. In Carroll, G. (Ed.), Ecological models of organizations. Ballinger, Cambridge, MA, pp.33-51.

Brau, J., Fawcett, S.E. 2006. Initial Public Offerings : An analysis of theory and practice. The Journal of Finance 61 (1), pp. 399-436.

Cassar, G., 2004. The financing of business start-ups. Journal of Business Venturing 19, pp.261-283.

Champenois, C., Engel, D., Heneric, O., 2006. What kind of German biotechnology start-ups do venture capital companies and corporate investors prefer for equity investors? Applied Economics, 38, pp. 505-518.

Chandler, N.G., Hanks, S.H. 1998. An examination of the substitutability of founders human and financial capital in emerging business ventures. Journal of Business Venturing 13, pp. 353-369.

Chrisman, J.J., Hynes, T., Fraser, S. 1995. Faculty entrepreneurship and economic development: The case of the university of Calgary. Journal of Business Venturing 10, pp. 267-281.

Clarysse, B., Knockaert, M., Lockett, A. 2007a. Outside Board Members in High-Tech Start-ups. Small Business Economics 29, pp. 243-259.

Clarysse, B., Wright, M., Lockett, A., Mustar, P., Knockaert. 2007b. Academic spin-offs, formal technology transfer and capital raising. Industrial and Corporate Change 16(4), pp. 609-640.

Colombo, M.G., Delmastro, M. 2002. How effective are technology incubators? Evidence from Italy. Research Policy, 31, pp.1103-1122.

Colombo, M.G. and Grilli, L. 2005. Founder's human capital and the growth of new technology-based firms: A competence-based view. Research Policy 34, pp. 795-816.

Colombo, M.G., Grilli, L., Piva, E. 2006. In search of complementary assets: the determinants of alliance formation of high-tech start-ups. Research Policy 35, pp. 1166-1199.

Colombo, M.G. and Grilli, L. 2007. Funding Gaps? Access to Bank Loans by High-Tech Start-Ups. Small Business Economics 29 (1-2), pp. 25-46.

Colombo, M.G., Grilli, L., Verga, C. 2007. High-tech start-up Access to public funds and Venture Capital: Evidence from Italy. International Review of Applied Economics. Vol. 21 (3), pp.381-402.

Colombo, M.G. and Grilli, L. 2009. On growth-drivers of high-tech start-ups: Exploring the role of founder's human capital and venture capital. Journal of Business Venturing, Forthcoming.

Cooper, A.C. and Bruno, A.V. 1977. Success among high-technology firms. Business Horizons 20(2), pp. 1622.

Dawson, A. 2009. Private equity investment decisions in family firms: The role of human resources and agency costs. Journal of Business Venturing. Forthcoming. 
Del Palacio, I., Solé, F. and Montiel, H. 2006. University spin-off programmes: How can theysupport NBTF creation? International Entrepreneurship and Management Journal, 2, pp.157-172.

Di Gregorio, D., Shane, S., 2003., Why do some universities generate more start-ups than others? Research Policy 32(2), pp.209-227.

Eisenhardt, K., Schoonhoven, C.B., 1990. Organizational Growth: linking founding team strategy, environment and growth among U.S. semiconductor ventures, 1979-1988. Administrative Science Quarterly 35, pp. 504-529.

Engel, D., Keilbach, M. 2007. Firm-level implications of early stage venture capital investment - An empirical investigation. Journal of Empirical Finance 14, pp. 150-167.

Ensley, M.D.; Hmieleski, K.M., 2005. A comparative study of new venture top management team composition, dynamics and performance between university based and independent start-ups. Research Policy 34, pp.1091-1105.

Geuna, A., Salter, A., Steinmueller, E., (Ed.), 2003. Science and Innovation. Rethinking the rationales for funding and governance. Cheltenham: Edward Elgar, pp.309-334.

Giot, P; Schwienbacher, A. 2007. IPO's, trade sales and liquidations: Modelling venture capital exits using survival analysis. Journal of Banking and Finance 31, pp. 679-702.

Giudici, G., Paleari, S. 2000. The provision of finance to innovation: A survey conducted among Italian technology-based firms. Small Business Economics 14, pp 37-53.

Griliches, Z. 1990. Patent statistics as economic indicators. Journal of Economic Literature. 28, pp. 1661-1707.

Heirman, A. Clarysse, B. 2004. How and why do Research-Based Start-Ups Differ at Founding? A ResourceBased Configurational Perspective. The Journal of Technology Transfer 29, pp. 247-268.

Hellmann, T., Puri, M., 2000. The interaction between product market and financing strategy: the role of venture capital. The Review of Financial Studies 13 (4), pp. 959-984.

Hellman, T., Puri, M. 2002. Venture Capital and the professionalization of start-up firms: Empirical evidence. The Journal of Finance 57, pp. 169-197.

Hogan, T., Hutson, E. 2005. What Factors Determine the Use of Venture Capital? Evidence from the Irish Software Sector. Venture Capital: An international journal of entrepreneurial finance 7(3), pp. 259-283.

Hopkins, H. 1988. Firm Size: The interchangeability of measures. Human Relations 41 (2), pp. 91-102.

Kaplan, S.N., Strömberg, P. 2004. Characteristics, contracts, and auctions: Evidence from Venture Capitalists Analyses. The journal of Finance. 59(5), pp. 2177-2210.

Kimberly, J.R., 1979. Issues in the creation of organizations: initiation, innovation and institutionalization. Academy of Management Journal 22, pp. 437-457.

Kortum, S.; Lerner, J. 2000. Assessing the contribution of Venture Capital to innovation. RAND Journal of Economics 31(4), pp. 674-692.

Lerner, J. 1998. Angel Financing and public policy: An overview. Journal of Banking and Finance, 22, pp. 773 783.

Lerner, J. 2002. When bureaucrats meet entrepreneurs: The design of effective public venture capital programmes. The economic journal, 112, pp. F73-F84.

Lockett, A., Murray, G, Wright, M. 2002. Do UK venture capitalists still have a bias against investment in new technology firms. Research Policy 31, pp. 1009-1030.

Lockett, A., Wright, M., Franklin, S. 2003. Technology transfer and university spin-out strategies. Small Business Economics 20, pp. 185-200.

Macmillan, I.C., Siegel, R., SubbaNarasimha, P.N. 1985. Criteria used by venture capitalists to evaluate new venture proposals. Journal of Business Venturing 1, pp. 119-128.

Macmillan, I.C., Zemann, L., SubbaNarasimha, P.N. 1987. Criteria distinguishing successful from unsuccessful ventures in the venture screening process. Journal of Business Venturing 2, pp. 123-137.

Macho-Stadler, I., Perez-Castrillo, D., Veugelers, R., 2007. Licensing of University Inventions: The role of a Technology Transfer Office. International Journal of Industrial Organization. 25 (3), pp.483-510.

Martí-Pellon, J. 2002. Oferta y demanda de capital riesgo en España. Ed. Civitas. 
Mowery, D., Nelson, R., Sampat B., Ziedonis, A., 2001. The growth of patenting and licensing by US universities: An assessment of the effects of the Bayh-Dole Act of 1980. Research Policy 30, pp.99-119.

Mustar, P., Renault, M., Colombo, M.G., Piva; E., Fontes, M., Lockett, A., Wright, M., Clarysse, B., Moray, N., 2006. Conceptualising the heterogeneity of research based spin-offs: A multi-dimensional taxonomy. Research Policy 35, pp.289-308.

Muzyka, C., Birley, S., Leleux, B. 1996. Trade-offs in the investment decisions of European venture capitalists. Journal of Business Venturing 11, pp. 273-287.

Ndonzuau, F.N, Pirnay, F., Surlemont, S., 2002. A stage model of Academic Spin-off creation. Technovation 22, pp.281-289.

Nelson, R., 2001. Observations on the Post-Bayh-Dole rise in patenting at American universities. The Journal of Technology Transfer 26, pp.13-19.

Ortín, P, Salas, V., Trujillo, M.V., Vendrell, F. 2008. La creación de spin-offs universitarios en España: características, determinantes y resultados. Economía Industrial 368, pp. 79-95

Ou, C., Haynes, G.W. 2006. Acquisition of Additional Equity Capital by Small Firms - Findings from the National Survey of Small Business Finances. Small Business Economics 27, pp. 157-168.

Patzelt, H., Knyphausen-Aufseß, D., Fischer, H., T. 2009. Upper echelons and portfolio strategies of venture capital firms. Journal of Business Venturing 24(6), pp. 558-572.

Quintana-García, C., Benavides-Velasco, C.A. 2005. Agglomeration economies and vertical alliances: a route to product innovation in biotechnology firms. International Journal of Production Research, 43, (22), pp.4853-73.

Roberts, E.B. 1991. Entrepreneurs in High-technology. Oxford University Press, New York.

Schartinger, D. Rammer, C., Fischer, M.M., Fröhlich, J. 2002. Knowledge interactions between university and industry in Austria: Sectoral patterns and determinants. Research Policy 31, pp. 303-328.

Shane, S., 2002. Selling University Technology: Patterns from MIT. Management Science 48, pp.122-137.

Shane, S., Stuart, T., 2002. Organizational endowments and the performance of university start ups. Management Science 48 (1), pp.154-170.

Shane, S. and Khurana R. 2003. Bringing individuals back in: The effects of career experience and new firm founding. Industrial and Corporate Change. 12 (3), pp. 519-543.

Shane, S. 2004. Academic Entrepreneurship: University Spin-offs and Wealth Creation. Edward Elgar, Cheltenham.

Shepherd, D.A., Ettenson, R., Crouch, A. (2000). New venture strategy and profitability : A venture capitalist's assessment. Journal of Business Venturing 15, pp. 449-467.

Siegel, D., Waldman, D., Link, A. 2003. Assessing the impact of organizational practices on the relative productivity of University Technology Transfer offices: An exploratory study. Research Policy Vol. 32, pp. 27-48.

Stohr, W.B. 1986. Regional innovation Complexes. Papers on the national science association 59, pp. 29-44.

Stuart, R.W., Abetti, P.A. 1990. Impact on entrepreneurial and management experience on early performance. Journal of Business Venturing 5(3), pp. 151-162.

Teece, D.J. 1986. Profiting from technological innovation: implications for technological integration, collaboration, licensing and public policy. Research Policy, 15, pp. 285-305.

Toole, A.A., Czarnitzki, D. 2007. Biomedical academic entrepreneurship through the SBIR program. Journal of Economic Behaviour \& Organization 63, pp. 716-738.

Van de Ven, A.H., Hutson, R. And Schroeder, D.M. 1984. Designing new business start-ups: entrepreneurial organisational and ecological considerations. Journal of Management 10 (1), pp. 87-107.

Vendrell-Herrero, F. (2008). Transfer of Knowledge from the lab to the market: The idiosyncrasy of academic entrepreneurs. Doctoral thesis Universitat Autónoma de Barcelona.

Vohora, A., Wright, M., Lockett, A., 2004. Critical junctures in the growth in university high-tech spinout companies. Research Policy 33, pp. 147-175.

Watson, R., Wilson, N. 2002. Small and medium size enterprise financing: a note on some of the empirical implications of a pecking order. Journal of Business Finance and Accounting 29 (3-4), pp. 557-578. 
Westhead, P., Storey, D. 1997. Financial constraints on the growth of high-technology small firms in the UK. Applied Financial Economics 7, pp. 197-201.

Wright, M., Birley, S., Mosey, S., 2004a. Entrepreneurship and university technology transfer 29, pp. 235-246.

Wright, M., Vohora, A., Lockett, A., 2004b. The formation of high-tech university spinout companies: the role of joint ventures and venture capital investors. Journal of Technology Transfer 29, pp. 287-310.

Wright, M., Lockett, A., Clarysse, B., Binks, M. 2006. University Spin-out companies and Venture Capital. Research Policy. 35, pp. 481-501.

$\mathrm{Xu}$, B. 1998. A reestimation of the Evans-Jovanovic entrepreneurial choice model. Economics Letters 58, pp.91-95. 
Table 1: A Comparison between university spin-offs and independent start-ups

\begin{tabular}{lccc}
\hline & University spin-offs & Independent start-ups & Full sample \\
Number of firms & 40 & 24 & 64 \\
Initial employees & 2.65 & 2.75 & 2.69 \\
Age & 5 & 6.7 & 5.66 \\
Computer Science & $37.5 \%$ & $20.8 \%$ & $31.2 \% *$ \\
Chemical & $17.5 \%$ & $20.8 \%$ & $18.7 \%$ \\
Pharmaceutics & $5 \%$ & $8.4 \%$ & $6.4 \%$ \\
Biotechnology & $15 \%$ & $16.7 \%$ & $15.6 \%$ \\
R\&D & $25 \%$ & $33.3 \%$ & $28.1 \%$ \\
employees and Age: Level of Statistical significance in the difference of mean between subsamples: $* * * 1 \%, * * 5 \%, * 10 \%$ \\
$:$ Pearson Chi ${ }^{2}$ (4) = 2.0859, we can not reject the possibility of the percentage distribution being the same among
\end{tabular}

Sectors: Pearson $\mathrm{Chi}^{2}(4)=2.0859$, we can not reject the possibility of the percentage distribution being the same among subsamples $[\mathrm{Pr}=0.720]$ 
Table 2: Variable Means

Firms that receive venture capital financing in comparison with those that do not

\begin{tabular}{lccc}
\hline & VC & NoVC & TOTAL \\
Computer Science & $\mathbf{2 2 . 2 \%}$ & $\mathbf{3 2 . 7 \%}$ & $\mathbf{3 1 . 2 \%}$ \\
Age & $\mathbf{6}$ & $\mathbf{5 . 5 8}$ & $\mathbf{5 . 6 6}$ \\
University spin-off & $\mathbf{8 8 . 8 \%}$ & $\mathbf{5 8 . 2 \%}$ & $\mathbf{6 2 . 5 \%}$ \\
USO with lack of managerial skills & $55.5 \%$ & $16.4 \%$ & $21.9 \%$ \\
USO with equal managerial skills & $33.3 \%$ & $41.8 \%$ & $40.6 \%$ \\
Current employees & $\mathbf{7 . 8 8}$ & $\mathbf{1 3 . 2 9}$ & $\mathbf{1 2 . 5 3}$ \\
Team size & $\mathbf{1 . 8 9}$ & $\mathbf{2 . 9 1}$ & $\mathbf{2 . 7 7}$ \\
IP protection rights & $\mathbf{1 . 5 5}$ & $\mathbf{1 . 2 9}$ & $\mathbf{1 . 3 3}$ \\
Unknown IP protection & $\mathbf{2 2 \%}$ & $\mathbf{2 0 \%}$ & $\mathbf{2 0 . 3 \%}$ \\
Degree of Debt & $\mathbf{5 3 \%}$ & $\mathbf{4 8 \%}$ & $\mathbf{4 9 \%}$ \\
\hline
\end{tabular}


Table 3: Do university spin-offs attract more venture capital?

\begin{tabular}{|c|c|c|c|}
\hline & \multirow{2}{*}{$\begin{array}{l}\text { Dependent variable: } \\
\text { Venture capital }\end{array}$} & \multicolumn{2}{|c|}{ Model 1} \\
\hline & & PROBIT & LOGIT \\
\hline \multirow[t]{3}{*}{ CONTROL VARIABLES } & Computer Science & $\begin{array}{c}-0.745 \\
(0.543)\end{array}$ & $\begin{array}{c}-1.376 \\
(1.054)\end{array}$ \\
\hline & Age & 0.094 & 0.167 \\
\hline & & $(0.070)$ & $(0.128)$ \\
\hline \multirow[t]{10}{*}{ H1 } & USO & $1.248 * *$ & $2.332 * *$ \\
\hline & & $(0.596)$ & $(1.199)$ \\
\hline & Constant & $\begin{array}{c}-2.339 * * * \\
(0.729)\end{array}$ & $\begin{array}{c}-4.172 * * * \\
(1.440)\end{array}$ \\
\hline & Pseudo- $\mathrm{R}^{2}$ & 0.1243 & 0.1214 \\
\hline & Log-likelihood & -22.758 & -22.835 \\
\hline & Observations & 64 & 64 \\
\hline & Correctly predicted & & \\
\hline & - $\quad$ Adopters of $V C$ & $77.78 \%$ & $77.78 \%$ \\
\hline & - $\quad$ Non-adopters of $V C$ & $58.18 \%$ & $58.18 \%$ \\
\hline & - $\quad$ Total & $60.94 \%$ & $60.94 \%$ \\
\hline
\end{tabular}

Level of Statistical significance: $* * * 1 \%, * * 5 \%, * 10 \%$. Standard error in parenthesis 
Table 4: Why do university spin-offs attract more venture capital?

\begin{tabular}{|c|c|c|c|c|c|c|c|}
\hline & Dependent variable: & & & & & & \\
\hline & Venture capital & PROBIT & LOGIT & PROBIT & LOGIT & PROBIT & LOGIT \\
\hline CONTROL & Computer Science & $\begin{array}{l}-0.847 \\
(0.592)\end{array}$ & $\begin{array}{l}-1.447 \\
(1.111)\end{array}$ & $\begin{array}{l}-1.343 \\
(0.830)\end{array}$ & $\begin{array}{l}-2.325 \\
(1.462)\end{array}$ & $\begin{array}{l}-1.347 \\
(1.0398)\end{array}$ & $\begin{array}{l}-2.294 \\
(1.778)\end{array}$ \\
\hline VARIABLES & Age & 0.097 & 0.172 & $\begin{array}{c}(0.030) \\
0.196\end{array}$ & $\begin{array}{c}(1.402) \\
0.348\end{array}$ & $\begin{array}{l}1.0790) \\
0.0709\end{array}$ & 0.133 \\
\hline & & $(0.073)$ & $(0.133)$ & $(0.140)$ & $(0.249)$ & $(0.160)$ & $(0.293)$ \\
\hline OTHER & Ln current employees & & & -0.521 & -0.954 & 0.245 & 0.442 \\
\hline EXPLANATIONS & & & & $(0.526)$ & $(0.945)$ & $(0.643)$ & $(1.175)$ \\
\hline EATLANATUNO & Team size & & & $-0.953 * *$ & $-1.667 * *$ & $-1.815^{* *}$ & $-3.135 * *$ \\
\hline & Degree of debt & & & $\begin{array}{c}(0.417) \\
0.892\end{array}$ & $\begin{array}{c}(0 . / / 2) \\
1.414\end{array}$ & $\begin{array}{c}(0.893) \\
2.393\end{array}$ & $\begin{array}{c}(1.537) \\
4.315\end{array}$ \\
\hline & Degrec of acor & & & $(0.917)$ & $\begin{array}{l}1.414 \\
(1.582)\end{array}$ & (1.619) & $(2.835)$ \\
\hline & IP protection & & & $0.180^{*}$ & $0.316^{*}$ & 0.251 ** & $0.434 * *$ \\
\hline & & & & $(0.109)$ & $(0.202)$ & $(0.128)$ & $(0.123)$ \\
\hline & Unknown IP & & & -0.115 & -0.042 & 0.549 & 0.957 \\
\hline & & & & $(0.655)$ & & $(0.775)$ & $(1.334)$ \\
\hline & USO & & & $1.975^{* *}$ & $\begin{array}{l}3.240^{* * *} \\
(1580)\end{array}$ & & \\
\hline & Lack of managerial skills & $1.769 * * *$ & $3.171 * * *$ & & & $4.143 * * *$ & $7.086^{* * * *}$ \\
\hline & & $(0.671)$ & $(1.293)$ & & & $(1.717)$ & $(2.963)$ \\
\hline H2 & Equal managerial skills & 0.888 & 1.689 & & & 1.648 & 2.729 \\
\hline & Constant & $-2.356 * * * *$ & $-4.209 * * *$ & -0915 & -1306 & $\frac{(1.021)}{-1.627}$ & $\frac{(1.150)}{2753}$ \\
\hline & & $(0.755)$ & $(1.477)$ & $(1,391)$ & $(2.506)$ & $(1.525)$ & $(2.735)$ \\
\hline & Pseudo- $\mathrm{R}^{2}$ & 0.1885 & 0.1820 & 0.3406 & 0.3278 & 0.4665 & 0.4555 \\
\hline & Log-likelihood & -21.090 & -21.260 & -17.137 & -17.41 & -13.865 & -14.152 \\
\hline & Observations & 64 & 64 & 64 & 64 & 64 & 64 \\
\hline & Correctly predicted & & & & & & \\
\hline & - $\quad$ Adopters of VC & $77.78 \%$ & $66.67 \%$ & $88.89 \%$ & $88.89 \%$ & $100 \%$ & $100 \%$ \\
\hline & - $\quad$ Non-adopters of $V C$ & $74.55 \%$ & $76.36 \%$ & $78.18 \%$ & $78.18 \%$ & $80 \%$ & $81.82 \%$ \\
\hline & - $\quad$ Total & $75 \%$ & $75 \%$ & $79.69 \%$ & $79.69 \%$ & $82.81 \%$ & $84.38 \%$ \\
\hline
\end{tabular}

Level of Statistical significance: $* * * 1 \%, * * 5 \%, * 10 \%$. Standard error in parenthesis 


\section{APPENDIX 1: QUESTIONNAIRE ON TECHNOLOGY-BASED COMPANIES}

(From A to D, Current situation; From D, Initial situation)

(The complete questionnaire contains 46 questions. We skipped the questions that do not concern variables presented in the paper)

\section{A. CURRENT COMPANY SITUATION}

A1. In what year was the company founded?

A2. Which economic activity sector does your company belong to? (R\&D, 1; I.T., 2; Chemicals, 3; Pharmaceuticals, 4; Biotechnology, 5; Other: Specify)

A3. How many people currently work in the company (including yourself)?

\section{B. INFORMATION ABOUT THE COMPANY'S FINANCING:}

B4. Please indicate approximately the proportion of the company assets that the following sources of financing represent.

\begin{tabular}{|l|l|}
\hline & Percentage of financing \\
\hline Founders / Promoters. & \\
\hline Family circle and friends (of the founders). & \\
\hline Financial entity. (shares) & \\
\hline Financial entity (debt). & \\
\hline Venture Capital. & \\
\hline University (shares) & \\
\hline University (debt) & \\
\hline Suppliers (debt). & \\
\hline Others. What? & \\
\hline
\end{tabular}

\section{INFORMATION ABOUT THE COMPANY'S MANAGEMENT:}

C5. Indicate the number of its own and other patents that the company works with. (Own patents, _ Own Brands, Licenses with universities; __ _ Licenses with Founders, __ ; Licenses with other companies,

Other (Specify)

\section{CHARACTERISTICS OF THE FOUNDERS.}

D6. With how many equivalent full-time staff did the company begin its activity?

\section{E. MOTIVATION OF THE FOUNDERS.}

E7. Could you please reply to the following aspects concerning the experience of the company founders/promoters at the moment of the company's creation?

\begin{tabular}{|c|c|c|c|c|c|c|c|c|}
\hline & \multicolumn{3}{|c|}{$\begin{array}{l}\text { Previous } \\
\text { experience } \\
\text { management in } \\
\text { activities? }\end{array}$} & \multirow[t]{2}{*}{$\begin{array}{ll}\text { Number } & \text { of } \\
\text { companies } & \\
\text { founded } & \\
\text { previously. } & \\
\end{array}$} & \multicolumn{4}{|c|}{ Educational Level at the moment of founding } \\
\hline & 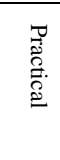 & 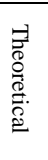 & 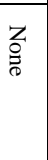 & & 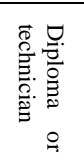 & 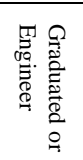 & 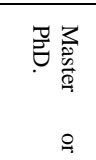 & Other (Specify) \\
\hline Founder/Promoter 1 & 1 & 2 & 3 & & 1 & 2 & 3 & \\
\hline Founder/Promoter 2 & 1 & 2 & 3 & & 1 & 2 & 3 & \\
\hline Founder/Promoter 3 & 1 & 2 & 3 & & 1 & 2 & 3 & \\
\hline Founder/Promoter 4 & 1 & 2 & 3 & & 1 & 2 & 3 & \\
\hline Founder/Promoter 5 & 1 & 2 & 3 & & 1 & 2 & 3 & \\
\hline
\end{tabular}

E8. Of the factors that are set out below, indicate which were the most relevant in the creation of the company. Please indicate their importance using a scale of 1 to 5 , where 1 signifies "minimal importance" and 5 "maximum importance".

\begin{tabular}{|l|c|}
\hline & Score (1 to 5) \\
\hline a. Detection of a business opportunity (an uncovered need) & \\
\hline b. Putting into practice previously acquired technical knowledge. & \\
\hline c. Desire to earn more money than working for a salary. & \\
\hline d. Prestige or status of the business person & \\
\hline e. Advantages of working for yourself. & \\
\hline f. The company you worked for suggested it or encouraged you. & \\
\hline g. Difficulties perceived in the previous professional career. & \\
\hline h. Others. Please describe & \\
\hline
\end{tabular}

F. FINANCING AT THE MOMENT OF FOUNDATION.

F9. With how much capital was the company set up? (Capital, $€$

F10. What proportion of this was put up by the founders? 